\title{
Effects of salinity and nutrient load and their interaction on Zostera marina
}

\author{
M. M. van Katwijk ${ }^{1, *}$, G. H. W. Schmitz ${ }^{1}$, A. P. Gasseling ${ }^{1}$, P. H. van Avesaath ${ }^{1,2}$ \\ 'Department of Aquatic Ecology and Environmental Biology, University of Nijmegen, Toernooiveld 1, 6525 ED Nijmegen, \\ The Netherlands \\ ${ }^{2}$ Netherlands Institute of Ecology, Centre for Estuarine and Coastal Ecology, Korringaweg 7, 4401 NT Yerseke, \\ The Netherlands
}

\begin{abstract}
Generally, seagrass Zostera marina L. distribution in the Wadden Sea and south-west Netherlands is limited to waters with low to moderate nutrient concentrations. However, it is known that $Z$. marina also occurs at high nutrient concentrations when growing in low salinity environments. In this study, we investigated the separate and interactive effects of nutrients and salinity on $Z$. marina plants in a $5 \mathrm{wk}$ experiment. Two populations were tested; one originating from a relatively marine habitat and the other from an estuarine habitat. Supplied salinities were 23,26 and $30 \% \mathrm{~S}$, and supplied water nutrient levels were nitrate:ammonium:phosphate, 1:3:2, 3:9:4.5 and 60:9:9 $\mu \mathrm{M}$ at a refreshment rate of $1 \mathrm{~d}^{-1}$, corresponding with a load of 20,95 and $625 \mathrm{~kg} \mathrm{~N} \mathrm{ha}^{-1} \mathrm{yr}^{-1} Z$. marina was negatively influenced by high salinity. The estuarine plants showed a decreased 'vitality' (calculated from 6 plant response parameters), whereas the marine plants showed a lesser number of shoots at high salinity. The negative effect acted on the estuarine plants at 26 and $30 \%, \mathrm{~S}$, and on the marine plants at $30 \% \mathrm{~S}$. At these high salinities, a high nutrient load had no detectable effect on the marine plants, whereas the estuarine plants were negatively influenced by high nutrient loads. At low salinity levels, i.e. marine plants at 23 and $26 \%$ S and estuarine plants at $23 \% \mathrm{~S}$, plants from both populations were positively influenced by higher nutrient loads. It is argued that these results may explain the distribution and decline of $Z$. marina in many areas of the northern hemisphere. Examples from both sides of the Atlantic Ocean are presented.
\end{abstract}

KEY WORDS: Eelgrass - Eutrophication - Interaction - Nitrogen - Phosphorus P Population dynamics . Salinity stress - Seagrass . Wadden Sea

\section{INTRODUCTION}

Deterioration of the seagrass Zostera marina L. has frequently been attributed to increased nutrient loading (e.g. Boynton et al. 1996, Short \& Burdick 1996). $Z$. marina is vulnerable to high nutrient concentrations in the water, either indirectly through algal blooms reducing light intensity (Neckles et al. 1993, Williams \& Ruckelshaus 1993, Harlin 1995, Short et al. 1995, Taylor et al. 1995) or directly via the adverse effects of either nitrate (Burkholder et al. 1992, 1994) or ammonium (van Katwijk et al. 1997).

Zostera marina occurs in waters with salinities ranging between 5 and $42 \%$ S (Tutin 1938, Luther 1951),

·E-mail: mvkatwyk@sci.kun.nl and seagrasses are adapted to cope with high salinity both physiologically and anatomically (e.g. Jagels 1983, Tyerman 1989, Arai et al. 1991, Pak et al. 1995, Fukuhara et al. 1996). However, few records exist of the effect of salinity on Zostera species. Pinnerup (1980) found a positive correlation between salinity and eelgrass productivity when investigating 3 Danish eelgrass beds situated at salinities between 13 and $31 \%$ S, while Wium-Andersen \& Borum (1984) found no effect of seasonal salinity variations on the annual life cycle of an eelgrass bed ranging in salinity from 9 to $23 \%$ S. Productivity of another Zostera species, $Z$. capensis Setchell, was negatively correlated with salinity in the range of 15 to $75 \%$ S (Adams \& Bate 1994). Photosynthesis of $Z$. japonica Aschers. \& Graebn. (sub nomine Z. nana) was optimal at $25 \%$ S (Ogata \& Matsui 1965). Wasting disease, which 
destroyed many eelgrass populations on both sides of the Atlantic Ocean during the 1930s (review in den Hartog 1996), did not occur in low salinity areas, which was generally attributed to the salinity optimum of the presumed disease-causing slime mold Labyrinthula: 22 to $40 \%$ S (Young 1943, Pokorný 1967. Rasmussen 1977). There is no consensus whether Labyrinthula was a causing agent, or merely a stress symptom in this large-scale decline (review in den Hartog 1996). Labyrinthula is present in most eelgrass beds (Vergeer \& den Hartog 1994)

In The Netherlands, with its variety of marine (ca $30 \%$ S) and estuarine (15 to $25 \%$ S) environments, we observed that the distribution of Zostera marina in marine environments was limited to waters with low to moderate nutrient concentrations, viz. in summer, monthly median values varied between 0 and $4 \mu \mathrm{M}$ $\mathrm{NO}_{3}, 1$ and $8 \mu \mathrm{M} \mathrm{NH}{ }_{4}, 2$ and $10 \mu \mathrm{M} \mathrm{P}$ tot and in winter between 15 and $55 \mu \mathrm{M} \mathrm{NO}_{3}, 7$ and $11 \mu \mathrm{M} \mathrm{NH}$, and 3 and $8 \mu \mathrm{M} \mathrm{P}_{\mathrm{tor}}$. Surprisingly however, $Z$. marina was observed to flourish in estuarine environments with relatively high nutrient concentrations, viz. in summer monthly median values vary between 0 and $90 \mu \mathrm{M}$ $\mathrm{NO}_{3}, 2$ and $11 \mu \mathrm{M} \mathrm{NH}, 7$ and $25 \mu \mathrm{M} \mathrm{P}_{\text {tol }}$; in winter between 50 and $260 \mu \mathrm{M} \mathrm{NO}_{3}, 15$ and $55 \mu \mathrm{M} \mathrm{NH}_{4}$, and 8 and $20 \mu \mathrm{M} \mathrm{P}_{\text {lot }}$ (Ministry of Transport Water Management and Public Works unpubl. data ). Furthermore, in some marine environments, seagrass distribution shifted towards areas with some freshwater influence (Burdick et al. 1993, D. J. de Jong pers. comm.). Finally, large-scale $Z$. marina disappearance was recorded in Lake Grevelingen, coinciding with a salinity increase (Wijgergangs 1994, Nienhuis et al. 1996). From this, we hypothesised that (1) a relatively low salinity is favourable for $Z$. marina, (2) nutrient availability and salinity have an interactive effect on $Z$. marina, the plants being able to tolerate higher nutrient concentrations at low salinity, but not at high salinity. Also, we were interested in knowing whether marine and estuarine populations exhibited a differential response when exposed to various salinity and nutrient treatments, as $Z$. marina populations are known to differ in habitat adaptation traits (e.g. Biebl \& McRoy 1971, van Katwijk et al. 1998).

In this study, the combined effect of salinity and nutrient load on Zostera marina survival was examined in plants originating from a marine and an estuarine habitat. Supplied salinity and nutrient levels ranged between late summer levels in a marine and an estuarine situation, in a relatively undisturbed and eutrophicated system. Late summer values were chosen, because (1) it was observed that Dutch Wadden Sea plants died prematurely in late summer, so late summer conditions seemed to be important for the condition of eelgrass, and (2) adverse effects of high nutrient loads were expected to be strongest when irradiance decreased and temperature was still high, as this results in a lower carbon fixation rate. Carbon is required to assimilate ammonium, which continuously enters the cells (Marschner 1995, van Katwijk et al. 1997)

\section{MATERIAL AND METHODS}

Zostera marina plants originating from 2 intertidal populations of a relatively marine (Terschelling) habitat and an estuarine (Eems) habitat, both located in the Dutch Wadden Sea (Fig. 1), were subjected in a laboratory set-up (Fig. 2) to salinities of $23 \% \mathrm{~S}(21.5$ to $24.0), 26 \% \mathrm{~S}(24.0$ to 27.0$)$ and $30 \% \mathrm{~S}$ (27.0 to 31.5 ), respectively, at 3 nutrient levels in the culture medium, nitrate:ammonium:phosphate, viz. 1:3:2, 3:9:4.5 and 60:9:9 $\mu \mathrm{M}$, which was supplied to glass containers at a refreshment rate of once per day, resulting in loads of ca 20,95 and $625 \mathrm{~kg} \mathrm{~N} \mathrm{ha}^{-1} \mathrm{yr}^{-1}$, and 20,45 and $100 \mathrm{~kg}$ $\mathrm{P} h \mathrm{a}^{-1} \mathrm{yr}^{-1}$, respectively (see 'Results'). Salinities applied ranged between the median summer level in a marine and an estuarine environment. The nutrient levels in the culture medium corresponded to the median late summer levels in the channels of the relatively undisturbed northern German Wadden Sea, the more eutrophicated Dutch Wadden Sea and the eutrophic Eems Estuary, respectively (R. M. Asmus pers. comm., Dutch Ministry of Transport, Public Works and Water Management unpubl. data).

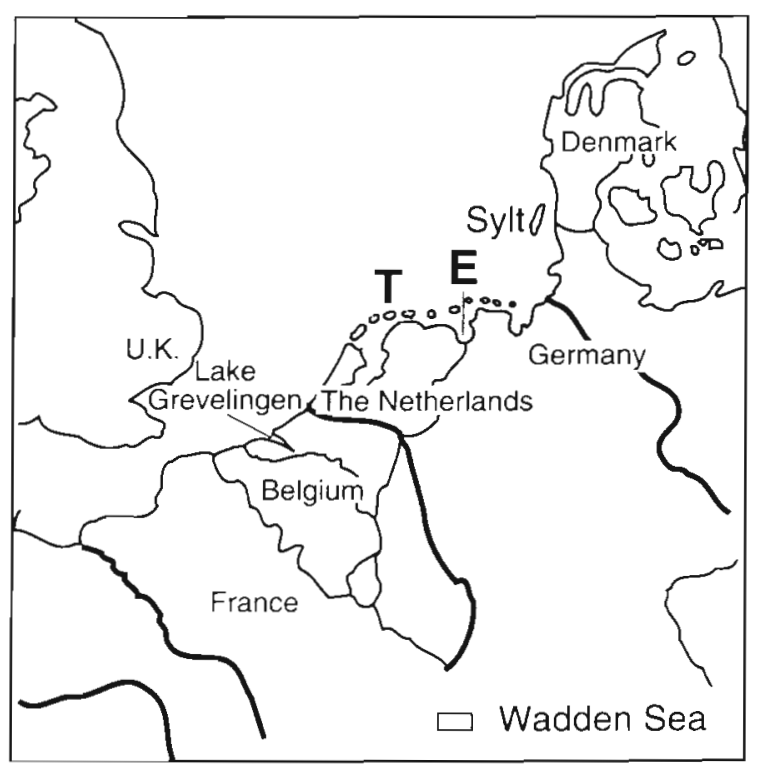

Fig. 1. Map showing locations of Zostera marina L populations of interest. T: Terschelling, E: Eems 


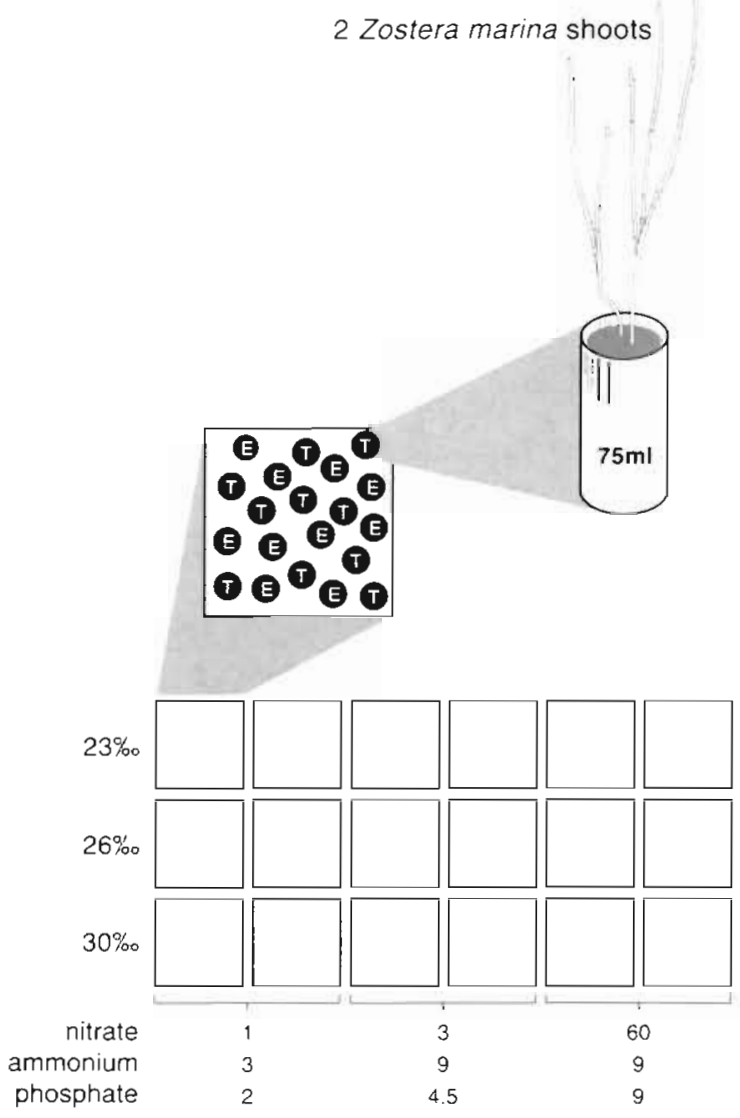

Fig. 2. Scheme of the experimental set-up. In the actual setup, the glass containers were randomly placed. Zostera marina plants originating from Terschelling $(T)$ and Eems (E). Supplied nutrient concentrations in $\mu \mathrm{M}$

Collection and culture conditions. Zostera marina plants were collected in Terschelling (11 August 1993) and Eems (10 August 1993). The plants, all having a growing apex and a rhizoom of ca $5 \mathrm{~cm}$ length, were maintained overnight at $16^{\circ} \mathrm{C}$. Wasting disease-like lesions were present in the leaves. The following day. pairs of plants were placed in $75 \mathrm{ml}$ jars filled with sieved (mesh $0.5 \mathrm{~cm}$ ), muddy sand originating from Eems. A thin layer of sand was placed over the sediment to prevent nutrient exchange with the overlying water. Twenty jars per container (10 with Terschelling and 10 with Eems plants) were placed in 18 glass containers of $15 \mathrm{l}$, and were allowed to acclimate for $3 \mathrm{wk}$ in synthetic seawater $(23,26$ and $30 \%$ S, Wimex, Wiegandt GmbH, Krefeld, Germany). From 3 September 1993, seawater composed of a self-prepared salt mix, derived from uncontaminated 'pro analysi' salts (Merck, Darmstadt, Germany) composition according to Pytkowicz et al. (1977) was used, to avoid nitrogen contamination found in all synthetic sea salt mixes that we tested (van Katwijk et al. 1997). Ammonium, nitrate and phosphate were added as potassium or chloride salts. The culture medium was continuously refreshed from stock containers using masterflex multichannel peristaltic pumps. Water in the containers was gently aerated to ensure complete mixing. For technical details of the set-up, see Roelofs et al. (1984). The plants were maintained at $17^{\circ} \mathrm{C}$ under an $8 \mathrm{~h}$ dark: $16 \mathrm{~h}$ light cycle; light intensity just below the water surface averaged at $95 \mu \mathrm{E} \mathrm{m}^{-2} \mathrm{~s}^{-1}$ (measured with a LiCor LI185 a with quantum sensor), which is saturating for Z. marina at this temperature (Marsh et al. 1986). Macroalgae and epiphytes were carefully removed daily or once in $2 \mathrm{~d}$, as we were interested in the effects of salinity and nutrients on $Z$. marina plants only. Simultaneously, detached leaves were removed, so hardly any leaf debris developed.

Sampling. Prior to the experiment, a sample of Zostera marina plants was taken from each population. Two and $5 \mathrm{wk}$ after the treatments commenced, $10 \mathrm{Z}$. marina plants (5 jars) of each population were sampled from each glass container, to measure the number of shoots, number of missing leaves, leaf length, width, dry weight, wasting disease-like lesions, necrosis, chlorophyll a (chl a), \% N and \% P in the aboveground parts. The sediments were sampled prior to the experiment, and after 2 and $5 \mathrm{wk}$, to measure waterextractable $\mathrm{NH}_{4}$ and total $\mathrm{P}$. The sediments of the 5 jars were mixed and stored at $4^{\circ} \mathrm{C}$. Water in the glass containers was sampled 8 times between 9 September and 5 October, to measure $\mathrm{NH}_{4}, \mathrm{NO}_{3}, \mathrm{PO}_{4}$ and $\mathrm{Cl}$ concentrations. The samples were filtered and stored at $-20^{\circ} \mathrm{C}$ for a maximun of 4 mo.

Plant analysis. When there were 3 or more leaves, we supposed that there were no missing leaves; 2 leaves present indicated 1 leaf was missing and 1 leaf present indicated 2 missing leaves. Leaf scores for wasting disease-like lesions and necrosis were based on the percentage of total leaf surface, estimated for each of the first 3 leaves separately. The leaf scores were averaged to calculate shoot values, whereby damage on young leaves was given a higher weight than damage on older leaves (the method of calculation as described in van Katwijk et al. 1997). A distinction was made between discoloured leaf surface and infected leaf surface, the former being used to assess necrosis (including wasting disease-like lesions), the latter to assess only wasting disease-like lesions. Three plants were freeze-dried over 24 to $48 \mathrm{~h}$ to determine dry weight.

To obtain a more complete and general description of the plant response per container, we calculated 'vitality':

vitality $=$ number of shoots + size - necrosis number of missing leaves 
in which size was the average between leaf length, width and total biomass of the plants. All parameters were standardised to mean 2 (to avoid negative values) and unit variance prior to the calculation (Jongman et al. 1995). The parameters were added rather than multiplied, because of their additive nature: they had a normal distribution (Slob 1987). A large number of missing leaves was considered to be a negative indication of plant vitality. Young shoots were not measured until they had roots of their own. Generally, they possessed 3 leaves at this stage.

Chl a was measured in leaf segments of 3 to $5 \mathrm{~cm}$ length which were taken from $3 \mathrm{~cm}$ below the apex of the first fully grown leaf. Epiphytes were removed by hand; however, this was seldom necessary. The segments of 2 shoots per glass container were pooled. The segments were blotted dry, weighed, ground in $80 \%$ ethanol and centrifuged. Chl a content in the supernatant was measured spectrophotometrically. Ca $2 \mathrm{ml}$ extractant per $10 \mathrm{mg}$ (fresh weight) of leaf material was used. The acidification method was used to correct for phaeophytin (Moed \& Hallegraeff 1978). Calculations of chl a were performed according to Roijackers (1981).

$\% \mathrm{~N}$ was measured in duplo, in $4 \mathrm{mg}$ of freeze-dried and ground plant material, using a Nitrogen, Carbon, Sulphur Analyzer (Carlo Erba Instruments NA 1500). Two or 3 shoots were used to analyse total P contents of the aboveground parts. Epiphytes were scraped off. Ca $100 \mathrm{~g}$ ashed plant material $\left(550^{\circ} \mathrm{C}, 4 \mathrm{~h}\right)$ was digested with $1 \mathrm{ml}$ aqua regia $\left(\mathrm{HNO}_{3}\right.$ and $\mathrm{HCl}, 65$ and $35 \%$ vol., respectively, diluted $1: 2$ with double-distilled water). When the material was not completely digested, the sample was evaporated and another $\mathrm{ml}$ of aqua regia was added. This process was repeated 3 times maximum. The volume of the digest was brought to $50 \mathrm{ml}$ with double-distilled water. Total $P$ was measured with an Inductively Coupled Plasma (ICP) spectrophotometer, type IL Plasma 200.

Sediment analysis. Seventy to $100 \mathrm{~g}$ of fresh sediment were placed in a $500 \mathrm{ml}$ polyethylene bottle with $200 \mathrm{ml}$ of double-distilled water and shaken for $1 \mathrm{~h}$. This mixture was centrifuged for $20 \mathrm{~min}$ at $11000 \mathrm{rpm}$ (maximum intrinsic rate of natural change, $I_{\max }=$ $19690 \times g$ ) and the supernatant was stored at $-20^{\circ} \mathrm{C}$ for max. $4 \mathrm{mo}$. $\mathrm{NH}_{4}$ content of the supernatant was measured colourimetrically with a Technicon AAII system according to Kempers \& Zweers (1986). Total P was measured with an ICP spectrophotometer, type IL Plasma 200.

Water analysis. $\mathrm{NH}_{4}, \mathrm{NO}_{3}, \mathrm{PO}_{4}$ and $\mathrm{Cl}$ content of the water samples were measured colourimetrically with a Technicon AAII system according to Kempers \& Zweers (1986), Grasshoff et al. (1983), Henriksen (1965) and O'Brien (1962), respectively. Salinity was calculated from $\mathrm{Cl}$ according to Stumm \& Morgan
(1981). Nutrient loads were calculated by subtracting the output concentrations (as measured in the glass containers) from the input concentrations in the supply containers, and subsequently converted to ha ${ }^{-1}$ and $\mathrm{yr}^{-1}$ reckoning with a refreshment rate of $1 \mathrm{~d}^{-1}$ and height of the overlying water of $0.2 \mathrm{~m}$.

Statistical analysis. All parameters were statistically analysed per glass container (number of missing leaves, leaf length, width, biomass, wasting diseaselike lesions and necrosis of the shoots were averaged per glass container prior to statistical analysis). Plant parameters were normally distributed, except for total P, which was lognormally distributed. Sediment and water parameters were lognormally distributed. The means or geometric means were used as a central measure. As a measure of variance, standard error of the mean was used. For lognormal parameters, the standard error of the mean was calculated according to Mood et al. (1974).

Analysis of Variance (ANOVA) was used in this splitplot experiment (population of origin being a subplot factor, the glass containers being the experimental unit), whereby salinity, nutrient treatment and their interaction were tested with the following error-term: salinity $\times$ nutrient treatment $x$ replicate + salinity $\times$ replicate + nutrient treatment $\times$ replicate, and the population and the interactions of population with the other parameters were tested against the residual error (Steel \& Torrie 1980, Freund \& Littell 1985). For comparison of means, Tukey's test was used. The ANOVA and Tukey's test were carried out using the Statistical Analysis System, procedure GLM (SAS 1989).

\section{RESULTS}

\section{Sediment and water}

The sediment $\mathrm{NH}_{4}$ and $\mathrm{P}_{\text {tot }}$ were not influenced by the nutrient treatment (ANOVA, $p>0.05$ ). Over the time course of the experiment, $\mathrm{NH}_{4}$ and $\mathrm{P}_{\text {tot }}$ concentrations in the sediment decreased (Table 1). $\mathrm{NO}_{3}$ and $\mathrm{PO}_{4}$ concentrations in the overlying water in the glass containers were positively influenced by nutrient treatment (ANOVA, $p<0.001$ on almost all dates of measurements), whereas water $\mathrm{NH}_{4}$ concentrations showed no correlation. The nutrient concentrations in the glass containers were lower than in the supply medium containers (Table 2).

\section{Zostera marina}

The nutrient treatments positively influenced aboveground tissue nutrient contents of the Zostera marina 
Table 1. Sediment water-extractable nutrient concentrations

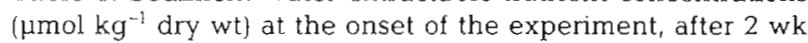
and after $5 \mathrm{wk}$. Geometric means (SE) of all treatments are presented

\begin{tabular}{|lccc|}
\hline & $\begin{array}{c}\text { Pre- } \\
\text { experiment }\end{array}$ & $2 w k$ & $5 w k$ \\
& & & \\
$\mathrm{NH}_{4}$ & $400(20)$ & $580(50)$ & $210(16)$ \\
$\mathrm{P}_{\text {tot }}$ & $89(0)$ & $31(2)$ & $29(4)$ \\
\hline
\end{tabular}

Table 2. Water nutrient concentrations and loads. Geometric means (SE) of the nutrient concentrations ( $\mu$ mol l-1) of 8 sampling dates are presented per nutrient treatment. Nutrient loads ( $\mathrm{kg} \mathrm{ha}^{-1} \mathrm{yr}^{-1}$ ) are presentedin italics; for calculation see 'Materials and methods'

\begin{tabular}{|cccc|}
\hline & Low & Medium & High \\
\hline $\mathrm{NH}_{4}$ & $1.6(0.2)$ & $2.0(0.4)$ & $1.8(0.4)$ \\
& 15 & 70 & 75 \\
$\mathrm{NO}_{3}$ & $0.4(0.1)$ & $0.4(0.1)$ & $6.3(3.2)$ \\
& 6 & 25 & 550 \\
$\mathrm{PO}_{4}$ & $1.1(0.1)$ & $2.5(0.1)$ & $4.5(0.4)$ \\
& 20 & 45 & 100 \\
& & & \\
\hline
\end{tabular}

plants after 5 wk (Figs. $3 \& 4$, Table 3). Aboveground tissue nitrogen content of the highest nutrient treatment was significantly higher than in shoots of the medium treatment, which, in turn, had higher nitrogen content than in the lowest nutrient treatment $(\mathrm{p}<0.05$, Tukey's test for comparison of means). Furthermore, the tissue nitrogen content at median nutrient treatment was higher at the highest salinity than at both lower salinities (Fig. 3), which is reflected in a significant effect of salinity and an interaction effect (Table 3). This effect was not present after 2 wk. Aboveground tissue phosphorus content of the intermediate salinity treatment was higher than in the low and high salinity treatments. In the Eems plants, tissue phosphorus was higher than in the Terschelling plants (Fig. 4, Table 3), which was already the case prior to the experiment.

Salinity had a negative effect on the number of Zostera marina shoots after $5 \mathrm{wk}$ of treatment (Fig. 5 , Table 3). The marine and estuarine populations responded differently to the salinity and nutrient treatments. The marine Terschelling plants responded merely by differences in the number of shoots. The highest salinity tested had a negative effect on the number of shoots. At this high salinity, nutrients had no effects (ANOVA, $\mathrm{p}>0.1, \mathrm{n}=2$ ). In the 2 lower salinity treatments, nutrients had a positive effect (ANOVA,

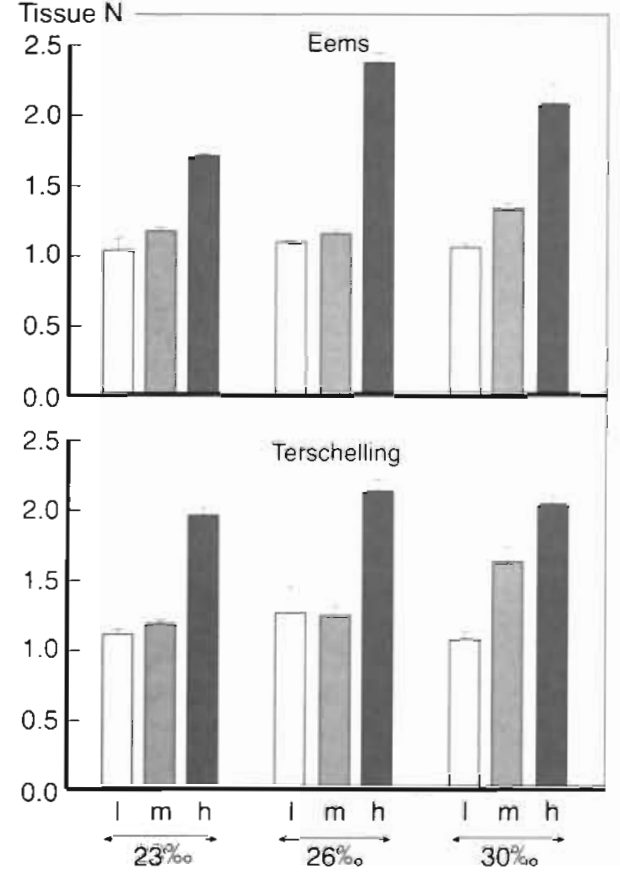

Fig. 3. \% $\mathrm{N}$ in aboveground tissue of Zostera marina after 5 wk at different combinations of salinity and nutrient loads. l: low, m: medium, h: high nutrient load. Means and SEM of 2 replicates are presented

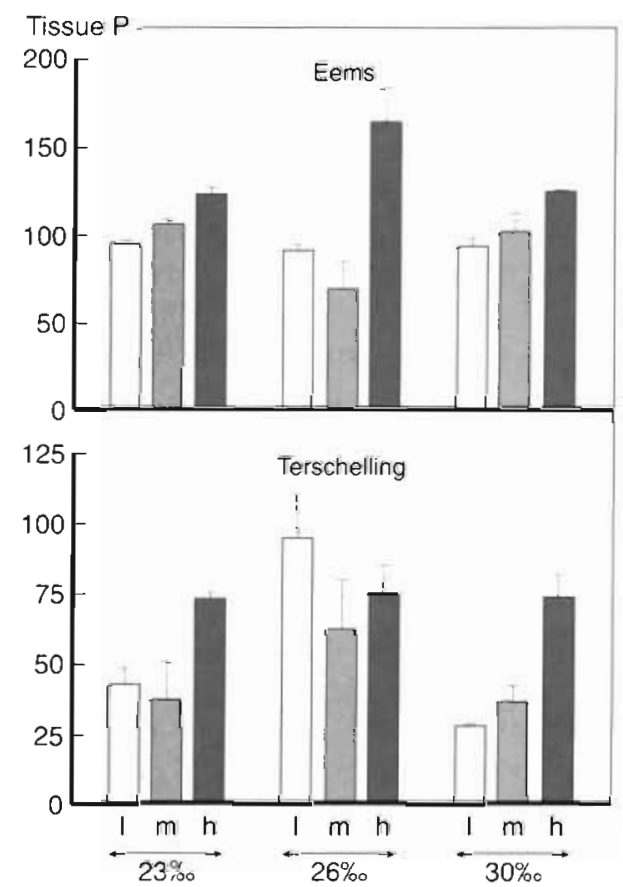

Fig. 4. $P_{\text {tot }}$ ( $\mu \mathrm{mol} \mathrm{g}{ }^{-1} \mathrm{dry} w \mathrm{t}$ ) in aboveground tissue of Zostera marina after $5 \mathrm{wk}$ at different combinations of salinity and nutrient loads. l: low, m: medium, h: high nutrient load. Geometric means and SEM of 2 replicates are presented 
Table 3. Split-plot ANOVA for effects of nutrient and salinity treatments, and population of origin of Zostera marina plants Ntr: nutrient, Sal: salinity, Pop: population. $0.01 \leq \mathrm{p} \leq 0.05$ $\cdots 0.001 \leq p \leq 0.01, \cdots p<0.001, n s: p>0.05$

\begin{tabular}{|c|c|c|c|c|c|}
\hline Treatment & MS & $F$ & $\mathrm{df}$ & $\mathrm{p}$ & Sign \\
\hline \multicolumn{6}{|c|}{$\% \mathrm{~N}$ in aboveground tissue } \\
\hline Ntr & 3.012 & 448.8 & 2 & $<0.001$ & $\cdots$ \\
\hline Sal & 0.125 & 18.7 & 2 & 0.001 & $\cdots$ \\
\hline Pop & 0.032 & 2.81 & 1 & 0.13 & ns \\
\hline $\mathrm{Ntr} \times \mathrm{Sal}$ & 0.090 & 13.4 & 4 & 0.001 & $\cdot \cdot$ \\
\hline Ntr $\times$ Pop & 0.017 & 1.46 & 2 & 0.28 & ns \\
\hline Sal $\times$ Pop & 0.009 & 0.79 & 2 & 0.49 & ns \\
\hline Ntr $\times$ Sal $\times$ Pop & 0.037 & 3.28 & 4 & 0.06 & ns \\
\hline \multicolumn{6}{|c|}{$P_{t o t}$ in aboveground tissue } \\
\hline Ntr & 0.768 & 29.17 & 2 & $<0.001$ & $\cdots$ \\
\hline Sal & 0.232 & 8.83 & 2 & 0.009 & $\cdot$ \\
\hline Pop & 3.715 & 82.0 & 1 & $<0.001$ & $\cdots$ \\
\hline $\operatorname{Ntr} \times \mathrm{Sal}$ & 0.083 & 3.13 & 4 & 0.79 & ns \\
\hline Ntr $\times$ Pop & 0.009 & 0.19 & 2 & 0.83 & ns \\
\hline Sal $\times$ Pop & 0.344 & 7.58 & 2 & 0.02 & $\cdot$ \\
\hline Ntr $\times$ Sal $\times$ Pop & 0.187 & 4.13 & 4 & 0.04 & " \\
\hline \multicolumn{6}{|c|}{ Number of shoots } \\
\hline Ntr & 22.75 & 5.13 & 2 & 0.04 & $\cdot$ \\
\hline Sal & 139.00 & 31.3 & 2 & $<0.001$ & $\cdots$ \\
\hline Pop & 7.11 & 0.45 & 1 & 0.52 & ns \\
\hline $\operatorname{Ntr} \times$ Sal & 28.50 & 6.42 & 4 & 0.01 & $\cdot$ \\
\hline Ntr $\times$ Pop & 45.86 & 2.90 & 2 & 0.11 & ns \\
\hline Sal $\times$ Pop & 20.11 & 1.27 & 2 & 0.32 & ns \\
\hline Ntr $\times$ Sal $\times$ Pop & 15.36 & 0.97 & 4 & 0.46 & ns \\
\hline \multicolumn{6}{|c|}{ Vitality (see 'Materials and methods') } \\
\hline Ntr & 2.31 & 0.47 & 2 & 0.64 & ns \\
\hline Sal & 24.87 & 5.06 & 2 & 0.04 & . \\
\hline Pop & 0.003 & 0.00 & 1 & 0.98 & ns \\
\hline Ntr $\times$ Sal & 3.80 & 0.77 & 4 & 0.57 & ns \\
\hline Ntr $\times$ Pop & 1.12 & 0.35 & 2 & 0.71 & ns \\
\hline Sal $\times$ Pop & 7.82 & 2.45 & 2 & 0.14 & ns \\
\hline Ntr $\times$ Sal $\times$ Pop & 4.24 & 1.33 & 4 & 0.33 & ns \\
\hline \multicolumn{6}{|l|}{ Chl a } \\
\hline Sal & 1658 & 2.22 & 2 & 0.17 & ns \\
\hline Pop & 1603 & 1.54 & 1 & 0.25 & ns \\
\hline Ntr $\times$ Sal & 1558 & 2.08 & 4 & 0.18 & ns \\
\hline Ntr $\times$ Pop & 319 & 0.31 & 2 & 0.74 & ns \\
\hline Sal $\times$ Pop & 166 & 0.16 & 2 & 0.85 & ns \\
\hline Ntr $\times$ Sal $\times$ Pop & 798 & 0.77 & 4 & 0.57 & ns \\
\hline
\end{tabular}

$p<0.01, n=4$ ) on the number of shoots (Fig. 5). The estuarine Eems plants responded to the treatments by differences in 'vitality' (see 'Materials and methods', Fig. 6). The 2 higher salinity treatments had a negative effect on vitality. In these treatments, nutrients had a negative effect (ANOVA, $p<0.01, n=4$ ). In the low salinity treatment, the Eems population tended to respond positively to nutrients (ANOVA, $\mathrm{p}=0.1, \mathrm{n}=2$ ). This complex response of vitality to the treatments resulted in hardly any significant treatment effects

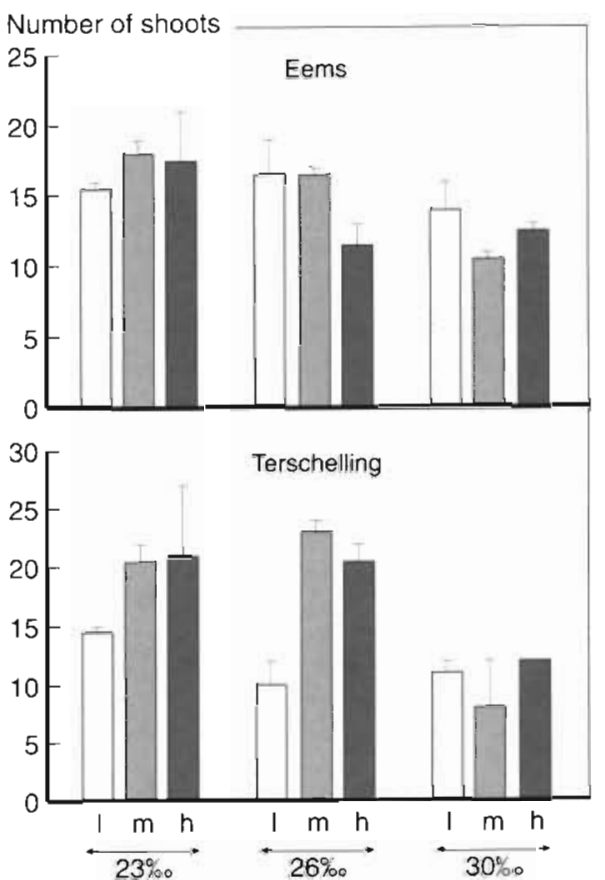

Fig. 5. Number of Zostera marina shoots after 5 wk at different combinations of salinity and nutrient loads. l: low, m: medium, h: high nutrient load. Means and SEM of 2 replicates are presented

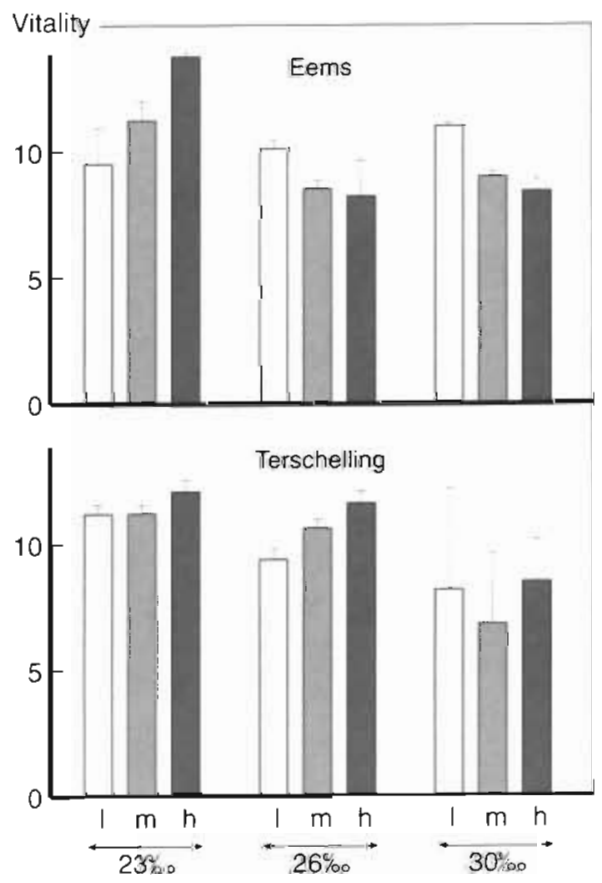

Fig. 6. Vitality of Zostera marina, a combined factor ('Materials and methods'), after 5 wk at different combinations of salinity and nutrient loads. 1: low, m: medium, h: high nutrient load. Means and SEM of 2 replicates are presented 


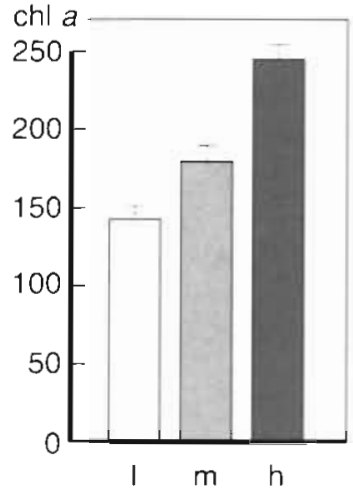

Fig. 7. Chlorophyll a concentrations ( $\mathrm{Hg} \mathrm{g}^{-1}$ fresh wt) in Zostera marina leaves in 3 nutrient treatments. I: low, $\mathrm{m}$ : medium, $\mathrm{h}$ : high nutrient load. Means and SEM of replicates, salinity treatments and population of origin are presented

when testing the overall effects in the split-plot ANOVA (Tab. 3).

Chl a was highest at the highest nutrient treatment in both Eems and Terschelling shoots (Fig. 7, Table 3).

\section{DISCUSSION}

In the sediment, water-extractable ammonium and total phosphorus decreased during the experiment, probably due to plant uptake. Phosphate decrease in the sediment may also have been caused by precipitation of iron phosphate due to oxygenation of the rhizosphere by Zostera marina roots. Nutrient uptake caused the nutrient levels in the water to drop below the levels that were continuously supplied from the culture medium, although the replenishment rate of the glass containers was high. This has no effect on the nitrogen loads. In this experiment the low, medium and high nutrient treatments corresponded with 20,95 and $625 \mathrm{~kg} \mathrm{~N} \mathrm{ha}^{-1} \mathrm{yr}^{-1}$. In comparison, the $\mathrm{N}$-load in the Dutch and German coastal zone of the North Sea, including the Wadden Sea, is estimated to be $340 \mathrm{~kg} \mathrm{~N}$ $\mathrm{ha}^{-1} \mathrm{yr}^{-1}$ on average (Höpner 1991). In 10 lagoons and estuaries along the eastern coast of the United States $N$-loads were $24,41,64,65,157,175,310,397,520$ and $624 \mathrm{~kg} \mathrm{~N} \mathrm{ha}{ }^{-1} \mathrm{yr}^{-1} ; Z$. marina occurred only at the sites with 24, 41 and $64 \mathrm{~kg} \mathrm{~N} \mathrm{ha}^{-1} \mathrm{yr}^{-1}$ (Boynton et al. 1996, McClelland \& Valiela 1998). Nutrient loads may have larger impacts on seagrass than nutrient concentrations (Tomasko et al. 1996).

After $5 \mathrm{wk}$, tissue nitrogen contents showed an interaction effect as a consequence of the salinity treatment. At high salinity, plant biomass per container was lower, leaving more ammonium in the water layer, resulting in higher tissue nitrogen contents. This artefact had only started to develop at the end of the experiment, and showed no correlation with the interaction effect of nutrients and salinity on the number of shoots and vitality of Zostera marina mentioned below.
Zostera marina plants, originating from the marine Terschelling habitat and the estuarine Eems habitat, were negatively influenced by high salinity. Vitality of the estuarine population la factor synthetised of number of shoots, plant size, necrosis and number of missing leaves) decreased at 26 and $30 \%$ salinity, whereas the marine population responded with a reduction of the number of shoots, at the $30 \%$ level only.

We did not find any effects of salinity on wasting disease. However, a positive relationship between salinity and the spread of wasting disease was observed in the 1930s (Pokorný 1967, Rasmussen 1977). Probably, Zostera marina populations occurring along the Atlantic coast in the 1930s were susceptible to wasting disease, whereas some of the present $Z$. marina populations on which the populations tested in our study, may have descended from plants that survived the disease, and may therefore be resistant to wasting disease. During the outbreak of wasting disease in the Wadden Sea, Harmsen (1936) observed that the intertidal narrow-leaved form of $Z$. marina seemed to be unaffected. There may still be populations that are susceptible to wasting disease, for example, Burdick et al. (1993) found correlations between salinity and wasting disease in Great Bay, New Hampshire.

The recent mass decline of Zostera marina in Lake Grevelingen (Nienhuis et al.1996), which Herman et al. (1996) attribute to the depletion of silicate, is in our opinion more likely explained by increased salinity. Salinity has increased in Lake Grevelingen as a consequence of changes in hydrological management (Nienhuis et al. 1996). This is further demonstrated by the inverse relationship between salinity and eelgrass cover in the period 1968 to 1992 (Wijgergangs 1994, M. M. van Katwijk \& D. J. de Jong unpubl. results).

Chl a content of the Zostera marina shoots increased with increasing nutrient loads in the water, as was found by Pedersen (1995).

When stressed by salinity, high nutrient loads did not benefit the marine Terschelling plants. The estuarine Eems plants were even negatively influenced by the high nutrient treatment. This is supported by field observations (see 'Conclusions and ecological implications'), but contradicts studies of salt-sensitive crop species, which showed an alleviating effect of nitrate on salinity stress (e.g. Marschner 1995). At low salinity levels (i.e. Terschelling plants 23 and 26\%; Eems plants $23 \%$ ), plants from both populations were positively influenced by the higher nutrient treatments.

Positive effects on Zostera marina from nutrient enrichment of the sediment have been reported previously (Orth 1977, Short 1983, 1987, Roberts et al. 1984, Kenworthy \& Fonseca 1992, Murray et al. 1992, Williams \& Ruckelshaus 1993, van Lent et al. 1995). Enrichment of the water column may also lead to 
increased growth of Z. marina (Harlin \& ThorneMiller 1981, Bohrer et al. 1995), but may also negatively affect $Z$. marina (Burkholder et al. 1992, 1994, Williams \& Ruckelshaus 1993, Taylor et al. 1995, Boynton et al. 1996, Nelson \& Waaland 1997, van Katwijk et al. 1997, McClelland \& Valiela 1998). Van Katwijk et al. (1997) found that toxic effects of ammonium were correlated with a shoot tissue nitrogen content in $Z$. marina leaves of $3.5 \%$ of the dry weight. In natural habitats, nitrogen content of $Z$. marina lies between 1 and $3 \%$ during the growing season, while in the present study, the shoot tissue nitrogen content in $Z$. marina leaves increased from 1.0 to $1.5 \%$ of the dry weight in both lowest nutrient treatments, to about $2.2 \%$ in the highest nutrient treatment. Therefore, the negative effects of water nutrient additions were not correlated to any toxic effect of $\mathrm{NH}_{4}$. Moreover, it is more likely that the plants were nutrient limited, causing a positive effect of water nutrient additions at low salinity. It remains to be explained why there is no positive effect, and even a negative effect in the case of the estuarine plants, of nutrient enrichment at high salinity.

The measured chemical composition of plant tissue (viz, aboveground and belowground tissue $\mathrm{N}, \mathrm{P}, \mathrm{C}, \mathrm{S}$, $\mathrm{Na} \mathrm{K}, \mathrm{Ca}, \mathrm{Mg}, \mathrm{Fe}$ and $\mathrm{Mn}$ ) gave no suggestion of a physiological mechanism which could be responsible for our results (see van Katwijk \& Schmitz 1999). However, a physiological explanation is not unlikely. It is known that nutrient-dependent processes like ammonium assimilation and amino acid metabolism are integrally involved in seagrass responses to salinity (Joshi et al. 1962, Pulich 1986). When subjected to high nitrogen loads, plants usually synthesise amino acids with a high $\mathrm{N}: \mathrm{C}$ ratio to prevent shortage of carbon which is required for ammonium assimilation (for example arginine, asparagine and glutamine, with $\mathrm{N}: \mathrm{C}$ ratios of $0.66,0.50$ and 0.40 , respectively; see Smolders et al. 1996). The amino acid proline accumulates in response to high salinity in Zostera marina and most other seagrass species, thereby acting as an osmoticum (Pulich 1986, van Diggelen et al. 1987, Adams \& Bate 1994). As proline has a $\mathrm{N}$ :C ratio of only 0.20 , carbon costs per nitrogen molecule will be high, which may cause $\mathrm{NH}_{4}$ toxicity due to carbon shortage.

Another explanation for the observed interactive effect of nutrients and salinity may arise from the growth rate and morphology of Zostera marina. Immature $Z$. marina leaf tissue is sensitive to salinity and is protected from seawater by tightly enveloping sheaths (Arai et al. 1991, Fukuhara et al. 1996). This was also found in other seagrasses by Tyerman (1989), who found an osmotic gradient in the 'sheath solution', i.e. the seawater that had diffused into the sheath, surrounding the immature tissue. In the direc- tion of the base, the osmolality decreased. Uptake of ions by the immature leaf caused this gradient, which, in turn, lessened the uptake load on the base (the expansion zone). Tyerman (1989) argues that the expansion zone of the leaf is shielded from high salinities provided that it continues to grow, since it is growth and the concomitant ion uptake which develop the gradient in the first place. Reversely, one may argue that a high growth rate may prematurely expose the leaf to seawater, thereby adversely affecting the plant. This is likely to occur at high nutrient loads and high salinity, and may therefore explain our results.

A third explanation may arise when considering that stressed plants (e.g. at high salinity) will have a lower growth rate, e.g. Grime (1979). The extra tissue nitrogen resulting from enrichment can be used for growth by plants with a high growth rate, in contrast to plants with a low growth rate, as was found by Pedersen (1995) in an enrichment experiment comparing fastgrowing macroalgae with slower-growing Zostera marina plants. After enrichment, Pedersen found increased tissue $\mathrm{N}$ and chl $a$ in both fast- and slowgrowing plants, which is consistent with our findings. Assuming that the low salinity plants in our experiment show the same response as Pedersen's macroalgae, viz. using the extra $N$ for growth, and furthermore assuming that the extra $\mathrm{N}$ may eventually burden the stressed high salinity plants, this would explain the nutrient $\times$ salinity effect found in our study.

The effect of salinity and the interactive effect of salinity and nutrients differed between the 2 populations, the marine (Terschelling) population responded negatively only to the highest salinity applied, whereas the estuarine (Eems) population responded negatively to both the highest and the intermediate salinity applied. In the present study, most of the differences measured between the populations at the onset of the experiment remained similar during the experiment, or became larger (see van Katwijk \& Schmitz 1999). This indicates either genotypic differences or phenotypic plasticity.

\section{CONCLUSIONS AND ECOLOGICAL IMPLICATIONS}

A salinity of $30 \%$ acted adversely on Zostera marina plants originating from the marine Terschelling habitat, while $Z$. marina plants from the estuarine Eems habitat were negatively effected by 26 and $30 \%$ salinity. When stressed by salinity, the plants responded either indifferently or negatively to nutrient enrichment, whereas at relatively low salinity, the plants were stimulated by enrichment. 
Although in a laboratory experiment only part of reality can be simulated, our findings are supported by, and may therefore explain, distribution patterns and dynamics of $Z$. marina observed (mentioned in the 'Introduction'). The results from this study indicate that an increased nutrient input in coastal areas will restrict of the distribution of $Z$ marina to areas with relatively low salinity. Without freshwater influence, a eutrophicated system will not be able to support $Z$. marina populations. Recent declines of $Z$. marina in areas at both sides of the Atlantic Ocean confirm this (Short et al. 1986, D. J. de Jong pers. comm.). Nutrient loads and salinities applied in this experiment cover the range present in the Wadden Sea (Hopner 1991, Ministry of Transport Water Management and Public Works unpubl. data), a range that is also frequently encountered along the eastern shores of the United States (e.g. Short et al. 1993, McClelland \& Valiela 1998), making our conclusions of interest to studies of $Z$. marina populations over a large geographical area.

Acknowledgements. This study has been financed by the Ministry of Transport, Public Works and Water Management. Thanks are due to Prof. Dr V. N. de Jonge of this Ministry for his skilful involvement in the project. We thank Dr J. G. M. Roelofs and L. S. A. M. Hanssen for fruitful discussions. Prof. Dr M. A. Hemminga, Dr J. G. M. Roelofs, Prof. Dr G. van der Velde, Prof. Dr C. den Hartog and B. Kelleher are thanked for critically reading the manuscript, the latter also for correcting the English. We thank D. C. R. Hermus, F. Looyen, E. Crins, M. Hornman, A. Janssen and workers of the Ministry of Transport, Public Works and Water Management for their assistance during the experiment. We thank J. Eygensteyn and G. Verheggen-Kleinheerenbrink for their help with the analyses. Dr R. M. Asmus (Biologische Anstalt Helgoland) and $A$. van der Pluym (National Institute for Coastal and Marine Management) kindly supplied us with nutrient and salinity data. The Illustration Service of the Faculty of Science, Universtity Nijmegen, is thanked for preparing the figures and T. de Boo (Department of Statistical Consultation, University Nijmegen) for help with the application of statistical methods.

\section{LITERATURE CITED}

Adams JB, Bate GC (1994) The tolerance to desiccation of the submerged macrophytes Ruppia cirrhosa (Petagna) Grande and Zostera capensis Setchell. J Exp Mar Biol Ecol 183:53-62

Arai M, Pak JY, Nomura K, Nitta T (1991) Seawater-resistant, non-spherical protoplasts from seagrass leaves. Physiol Plant 83:551-559

Biebl R, McRoy CP (1971) Plasmatic resistance and rate of respiration and photosynthesis of Zostera marina at different salinities and temperatures. Mar Biol 8:48-56

Bohrer T, Wright A, Hauxwell J, Valiela I (1995) Effect of epiphyte biomass on growth rate of Zostera marina in estuaries subject to different nutrient loading. Biol Bull $189: 260$
Boynton WR, Murray L, Hagy JD, Stokes C, Kemp WM (1996) A comparative analysis of eutrophication patterns in a temperate coastal lagoon. Estuaries 19:408-421

Burdick DM, Short FT, Wolf J (1993) An index to assess and monitor the progression of wasting disease in eelgrass Zostera marina. Mar Ecol Prog Ser 94:83-90

Burkholder JM, Mason KM, Glasgow HB (1992) Water-column nitrate enrichment promotes decline of eelgrass Zostera marina: evidence from seasonal mesocosm experiments. Mar Ecol Prog Ser 81:163-178

Burkholder JM, Glasgow HB Jr, Cooke JE (1994) Comparative effects of water-column nitrate enrichment on eelgrass Zostera marina, shoalgrass Halodule wrightii, and widgeongrass Ruppia maritima. Mar Ecol Prog Ser 105: $121-138$

den Hartog C (1996) Sudden declines of seagrass beds: 'wasting disease' and other disasters. In: Kuo J, Phillips RC, Walker DI, Kirkman H (eds) Seagrass biology: proceedings of an International Workshop. Rottnest Island, Western Australia, 25-29 January 1996. University of Western Australia, Nedlands, p 307-314

Freund RJ, Littell RC (1985) SAS for linear models. A guide to the ANOVA and GLM procedures. SAS Institute Inc, Cary, NC

Fukuhara T, Pak UY, Ohwaki Y, Tsujimura H, Nitta T (1996) Tissue-specific expression of the gene for a putative plasma membrane $\mathrm{H}^{+}$-ATPase in a seagrass. Plant Physiol 110:35-42

Grasshoff K, Ehrhardt M, Kremlin K (1983) Methods of seawater analysis. Verlag Chemie $\mathrm{GmbH}$, Weinheim

Grime JP (1979) Plant strategies and vegetation processes John Wiley \& Sons, Chichester

Harlin MM (1995) Changes in major plant groups following nutrient enrichment. In: MCComb AJ (ed) Eutrophic shallow estuaries and lagoons. CRC Press, Boca Raton, p $173-188$

Harlin MM, Thorne-Miller B (1981) Nutrient enrichment of seagrass beds in a Rhode Island coastal lagoon. Mar Biol 65:221-229

Harmsen GW (1936) Systematische Beobachtungen der Nordwest-Europäischen Seegrasformen. Ned Kruidkd Arch 46:852-877

Henriksen A (1965) An automated method for determining low level concentration of phosphate in fresh and saline waters. The Analyst 90:29-34

Herman PMJ, Hemminga MA, Nienhuis PH, Verschuure JM, Wessel EGJ (1996) Wax and wane of eelgrass Zostera marina and water column silicon levels. Mar Ecol Prog Ser $144: 303-307$

Höpner T (1991) The ecological state of the Wadden Sea. An assessment. Int Rev Ges Hydrobiol 76:317-326

Jagels R (1983) Further evidence for osmoregulation in epidermal leaf cells of seagrasses. Am J Bot 70:327-333

Jongman RHG, ter Braak CJF, van Tongeren OFR (1995) Data analysis in community and landscape ecology. Cambridge University Press, Cambridge

Joshi G, Dolan T, Gee R, Saltman P (1962) Sodium chloride effect on dark fixation of $\mathrm{CO}_{2}$ by marine and terrestrial plants. Plant Physiol 37:446-449

Kempers AJ, Zweers A (1986) Ammonium determination in soil extracts by the salicylate method. Commun Soil Sci Plant Anal 17:715-723

Kenworthy WJ, Fonseca MS (1992) The use of fertilizer to enhance growth of transplanted seagrasses Zostera marina L. and Halodule wrightii Aschers. J Exp Mar Biol Ecol 163:141-161

Luther H (1951) Verbreitung und Ökologie der höheren 
Wasserpflanzen im Brackwasser der Ekenäs-Gegend in Südfinnland. Acta Bot Fenn 50:1-72

Marschner H (1995) Mineral nutrition of higher plants. Academic Press, London

Marsh JA, Dennison WC, Alberte RS (1986) Effects of temperature on photosynthesis and respiration in eelgrass (Zostera marina L.). J Exp Mar Biol Ecol 101:257-267

McClelland JW, Valiela I (1998) Changes in food web structure under the influence of increased anthropogenic nitrogen inputs to estuaries. Mar Ecol Prog Ser 168: $259-271$

Moed JR, Hallegraeff GM (1978) Some problems in the estimation of chlorophyll- $\alpha$ and phaeo-pigments from preand post-acidification spectrophotometric measurements. Int Rev ges Hydrobiol 63:787-800

Mood AM, Graybill FA, Boes DC (1974) Introduction to the theory of statistics. McGraw-Hill, Kogakusha

Murray L, Dennison WC, Kemp WM (1992) Nitrogen versus phosphorus limitation for growth of an estuarine population of eelgrass (Zostera marina L.). Aquat Bot 44:83-100

Neckles HA, Wetzel RL, Orth RJ (1993) Relative effects of nutrient enrichment and grazing on epiphyte-macrophyte (Zostera marina L.) dynamics. Oecologia 93:285-295

Nelson TA, Waaland JR (1997) Seasonality of eelgrass, epiphyte, and grazer biomass and productivity in subtidal eelgrass meadows subjected to moderate tidal amplitude. Aquat Bot 56:51-74

Nienhuis PH, de Bree BHH, Herman PMJ, Holland AMB, Verschuure JM, Wessel EGJ (1996) Twenty-five years of changes in the distribution and biomass of eelgrass, Zostera marina, in Grevelingen Lagoon, The Netherlands. Neth J Aquat Ecol 30:107-117

O'Brien J (1962) An automated analysis of chlorides in sewage wastes. Engineering 33:670-672

Ogata E, Matsui T (1965) Photosynthesis in several marine plants of Japan as affected by salinity, drying and $\mathrm{pH}$, with attention to their growth habitats. Bot Mar 8:199-217

Orth RJ (1977) Effect of nutrient enrichment on growth of the eelgrass Zostera marina in the Chesapeake Bay, Virginia, U.S.A. Mar Biol 44:187-194

Pak JY, Fukuhara T, Nitta T (1995) Discrete subcellular localization of membrane-bound ATPase activity in marine angiosperms and marine algae. Planta 196:15-22

Pedersen MF (1995) Nitrogen limitation of photosynthesis and growth: comparison across aquatic plant communities in a Danish estuary (Roskilde Fjord). Ophelia 41:261-272

Pinnerup SP (1980) Leaf production of Zostera marina L. at different salinities. Ophelia (Suppl 1):219-224

Pokorný KS (1967) Labyrinthula. J Protozool 14:697-708

Pulich WM (1986) Variations in leaf soluble amino acids and ammonium content in subtropical seagrasses related to salinity stress. Plant Physiol 80:283-286

Pytkowicz RM, Atlas E, Culberson CH (1977) Some considerations of chemical equilibrium in the oceans. Oceanogr Mar Biol Annu Rev 15:15-45

Rasmussen E (1977) The wasting disease of eelgrass (Zostera marina) and its effect on environmental factors and fauna. In: McRoy CP, Helfferich C (eds) Seagrass ecosystems. a scientific perpective. M Dekker Inc, New York, p 1-51

Roberts MH, Orth RJ, Moore KA (1984) Growth of Zostera marina L. seedlings under laboratory conditions of nutrient enrichment. Aquat. Bot 20:321-328

Roelofs JGM, Schuurkes JAAR, Smits AJM (1984) Impact of acidification and eutrophication on macrophyte communities in soft waters. II. Experimental studies. Aquat Bot 18 : $389-411$

Roijackers RMíi (1981) A comparison between two methods of extracting chlorophyll- $\alpha$ from different phytoplankton samples. Hydrobiol Bull 15:179-183

SAS (1989) SAS/STAT user's guide, Version 6. SAS Institute Inc, Cary, NC

Short FT (1983) The seagrass Zostera marina L.: plant morphology and bed structures in relation to sediment ammonium in Izembek lagoon, Alaska. Aquat Bot 16:149-161

Short FT (1987) Effects of sediment nutrients on seagrasses: literature review and mesocosm experiment. Aquat Bot $27: 41-57$

Short FT, Burdick DB (1996) Quantifying eelgrass habitat loss in relation to housing development and nitrogen loading in Waquoit Bay, Massachusetts. Estuaries 19:730-739

Short FT, Mathieson AC, Nelson JI (1986) Recurrence of the eelgrass wasting disease at the border of New Hampshire and Maine, USA. Mar Ecol Prog Ser 29:89-92

Short FT, Burdick DM, Wolf JS, Jones GE (1993) Eelgrass in estuarine research reserves along the east coast, USA, Part I: declines from pollution and disease and Part II: management of eelgrass meadows. NOAA-Costal Ocean Program Publ, Durham

Short FT, Burdick DM, Kaldy JE (1995) Mesocosm experiments quantify the effects of eutrophication on eelgrass, Zostera marina. Limnol Oceanogr 40:740-749

Slob W (1987) Strategies in applying statistics in ecological research. Thesis, Vrije Universiteit, Amsterdam

Smolders A, van Gestel CBL, Roelofs JGM (1996) The effects of ammonium on growth, accumulation of free amino acids and nutritional status of young phosphorus deficient Stratiotes aloides plants. Aquat Bot 53:85-96

Steel RGD, Torrie JH (1980) Principles and proceedings of statistics. A biometrical approach. McGraw-Hill Inc Kogakusha

Stumm W, Morgan JJ (1981) Aquatic chemistry. An introduction emphasizing chemical equilibria in natural waters John Wiley \& Sons, New York

Taylor DI, Nixon SW, Granger SL, Buckley BA, MCMahon JP, Lin HJ (1995) Responses of coastal lagoon plant communities to different forms of nutrient enrichment: a mesocosm experiment. Aquat Bot 52:19-34

Tomasko DA, Dawes CJ, Hall MO (1996) The effects of anthropogenic mutrient enrichment on turtle grass (Thalassia testudinum) in Sarasota Bay, Florida. Estuaries 19 $448-456$

Tutin TG (1938) The autecology of Zostera marina in relation to its wasting disease. New Phytol 37:50-71

Tyerman SD (1989) Solute and water relations of seagrasses. In: Larkum AWD, McComb AJ, Shepherd SA (eds) Biology of seagrasses. Elsevier, Amsterdam, p 723-754

van Diggelen J, Rozema J, Broekman R (1987) Mineral composition of and proline accumulation by Zostera marina L. in response to environmental salinity. Aquat Bot 27 : $169-176$

van Katwijk MM, Schmitz GHW (1999) The effects of salinity and nutrient level and their interaction on Zostera marina L. plant originating from the estuarine Eems population and the marine Terschelling population in The Netherlands. Department of Aquatic Ecology and Environmental Biology, University of Nijmegen, Nijmegen

van Katwijk MM, Vergeer LHT, Schmitz GHW, Roelofs JGM (1997) Ammonium toxicity in eelgrass Zostera marina. Mar Ecol Prog Ser 157:159-173

van Katwijk MM, Schmitz GHW, Hanssen LSAM, den Hartog C (1998) Suitability of Zostera marina populations for transplantation to the Wadden Sea as determined by a mesocosm shading experiment. Aquat Bot 60:283-305

van Lent F, Verschuure JM, van Veghel MLJ (1995) Compar- 
ative study on populations of Zostera manina L. (eelgrass): in situ nitrogen enrichment and light manipulation. J Exp Mar Biol Ecol 185:55--76

Vergeer LHT, den Hartog C (1994) Omnipresence of Labyrinthulaceae in seagrasses. Aquat Bot 48:1-20

Wijgergangs LJM (1994) Zeegras in het Grevelingenmeer en de Oosterschelde, relatie met voedingsstoffen en zoutgehalte. University of Nijmegen, Nijmegen

Williams SL, Ruckelshaus MH (1993) Effects of nitrogen avail-

Editorial responsibility: Otto Kinne (Editor),

Oldendorf/Luhe, Germany ability and herbivory on eelgrass (Zostera marina) and epiphytes. Ecology $74: 904-918$

Wium-Andersen S, Borum J (1984) Biomass variation and autotrophic production of an epiphyte-macrophyte community in a coastal Danish area: I eelgrass (Zostera manina L.) biomass and net production. Ophelia 23:33-46

Young EL III (1943) Studies on Labyrinthula. The etiologic agent of the wasting disease of eel-grass. Am J Bot 30: $586-593$

Submitted: July 23, 1998; Accepted: August 17, 1999

Proofs received from author(s): November 24, 1999 